\title{
Quantitative biofilm for bacterial pathogens of ventilator-associated pneumonia
}

\author{
Fitri Hapsari Dewi ${ }^{1,2} \square$, Suradi ${ }^{3} \square$, Bambang Purwanto ${ }^{4} \square$, Brian Wasita ${ }^{5} \square$
}

Authors' affiliations:

1- Doctoral Program, Faculty of Medicine, Universitas Sebelas Maret, Surakarta, Indonesia.

2- Department of Anesthesiology and Intensive Therapy, Dr. Moewardi General Hospital, Surakarta, Indonesia.

3- Department of Pulmonology and Respiratory Medicine, Dr. Moewardi General Hospital, Faculty of Medicine, Universitas Sebelas Maret, Surakarta, Indonesia.

4- Department of Internal Medicine, Dr. Moewardi General Hospital, Faculty of Medicine, Universitas Sebelas Maret, Surakarta, Indonesia.

5- Department of Anatomical Pathology. Dr. Moewardi General Hospital, Faculty of Medicine, Universitas Sebelas Maret, Surakarta, Indonesia.

Correspondence: Fitri Hapsari Dewi, Department of Anesthesiology and Intensive Therapy, Dr. Moewardi General Hospital, Jalan Ir. Sutami 36 Kentingan, Jebres, Surakarta, Jawa Tengah. Indonesia 57126; E-mail: rieffid14@gmail.com

\section{Abstract}

Background \& Objective: Ventilator-associated pneumonia (VAP) is one of the most common nosocomial infections in clinical care settings. Several bacteria with biofilm-producing ability offer serious challenge in their eradication. Prompt and accurate diagnosis is needed to provide the best care for the patients. This study aimed to analyze whether biofilm examination using quantitative method can be used as a diagnostic tool for bacterial pathogens associated with VAP.

Methodology: This observational analytical study was conducted in Intensive Care Units of three teaching hospitals in Surakarta, Central Java, Indonesia, from November 2019 to April 2020. The subjects were between 19 and 65 y old, with a newly introduced endotracheal tube (ETT) connected to mechanical ventilators, and without pneumonia. Biofilm quantitative measurement used a microtiter plate method from bacterial culture found on ETT at the 48th hour after being mechanically ventilated. The Clinical Pulmonary Infection Score (CPIS) assessment was done at the 48th hour and CPIS of less than 6 was defined as VAP. The analysis used Spearman's rank and Kendall tau-b correlation. The samples were taken using a consecutive sampling technique.

Results: A significant correlation between biofilm and VAP was found ( $\rho=0.039, p<0.05$ ). Biofilm was also sufficiently correlated with an increase in CPIS ( $\tau b=0.341, p<0.05$ )

Conclusions: Quantitative biofilm can be used as a diagnostic tool for establishing the diagnosis of VAP so that appropriate therapy can be administered immediately.

Key words: Bacterial pathogen; Biofilm; Ventilator-associated pneumonia

Abbreviations: CPIS: Clinical Pulmonary Infection Score; VAP: Ventilator-associated pneumonia; ETT: Endotracheal tube; PCR: Polymerase chain reaction; OD: Optical density

Citation: Dewi FH, Suradi, Purwanto B, Wasita B. Quantitative biofilm for bacterial pathogens of ventilatorassociated pneumonia. Anaesth. pain intensive care 2021;25(2):132-137. DOI: 10.35975/apic.v25i2.1468

Received: 24 September 2020, Reviewed: 27, 30 October 2020, Accepted: 3 March 2021 


\section{Introduction}

Intubation using endotracheal tube (ETT) increases the risk of lung infection by 6-10 times compared to nonintubation. ${ }^{1}$ Intubation opens epiglottis, disrupting cough reflex, mucociliary clearance disorder, and enables bacteria to bind with tracheal and bronchial cells. $^{2}$ Application of mechanical ventilator connected to ETT can lead to lung infection, known as ventilator associated pneumonia (VAP) with Clinical Pulmonary Infection Score (CPIS) of $\geq 6$. Secretion originating from the oropharynx or gastrointestinal tract is common to cover ETT balloon, which facilitates microaspiration. This condition provides an ideal environment for bacterial biofilm. ${ }^{3}$ Biofilm formation in this area is one of the main causes of VAP. ${ }^{4}$

Biofilm is a form of bacterial survival mechanism to avoid host defense system; and it is one of the virulence factors in bacterial infection cases.$^{5,6}$ Biofilm can be found in implants or other devices fitted to patients. Endocarditis, septic arthritis, and VAP are some of the consequences of the biofilm. Detecting biofilm and identifying appropriate biofilm eradication agents are important for establishing correct diagnosis and management of sepsis. ${ }^{1,5,7,8}$

Biofilm can be examined by various methods, including roll plate, tube method, polymerase chain reaction (PCR), and microtiter plate. ${ }^{9}$ Microtiter plate is the most common method for examining biofilm. It is done by measuring the amount of biofilm on the plate quantitatively using a microELISA method. This method requires bacterial growth in the plate, which is then stained with a non-specific stain. After staining, the plate is then washed using ethanol $90 \%-95 \%$, pure ethanol, or mixed with acetone or acetate acid. The stained bacteria are then measured using UV spectrometer with a wavelength of 530-600 nm. Biofilm examination using a microtiter plate method is cheap, easy, and efficient as we can examine some samples at once. ${ }^{10,11} \mathrm{We}$ used the microtiter plate method to examine the biofilm in which result can be used as an alternative diagnostic tool for VAP, leading to proper therapy.

\section{Methodology}

It was an observational analytical study using prospective cohort design conducted from November
2019 to April 2020, in three teaching hospitals in Surakarta, Central Java, Indonesia. The samples were taken by the consecutive sampling technique. Patients aged between 19 and $65 \mathrm{y}$, with newly inserted ETT connected to mechanical ventilators and without pneumonia, were included in the study. We excluded pregnant patients, those with bronchiectasis and fibrosis.

We used sputum samples at 48th h post-mechanical ventilation initiation. The samples were determined whether they were adequate or poor in quality, and only adequate sputum samples were analyzed for bacterial culture and quantitative biofilm measurement using a microtiter plate method. Biofilm examination result was then interpreted as strong biofilm if the optical density (OD) of the stained bacteria was more than 4x ODc value, moderate biofilm if bacterial OD was $>2 x$ and $\leq 4 x$ ODc, weak biofilm if bacterial OD

Table 1: Clinical Pulmonary Infection Score used in this study

\begin{tabular}{|c|c|c|}
\hline Parameter & Result & Score \\
\hline \multirow[t]{3}{*}{ Temperature $\left({ }^{\circ} \mathrm{C}\right)$} & $36.5-38.4$ & 0 \\
\hline & $38.5-38.9$ & 1 \\
\hline & $\leq 36$ or $\geq 39$ & 2 \\
\hline \multirow{3}{*}{$\begin{array}{l}\text { Leukocytes } \\
\left(\text { cells } / \mathrm{mm}^{3}\right)\end{array}$} & $4.000-11.000$ & 0 \\
\hline & $<4.000$ or $>11.000$ & 1 \\
\hline & $\geq 500$ band cells & 2 \\
\hline \multirow{3}{*}{$\begin{array}{l}\text { Tracheal } \\
\text { secretions } \\
\text { (subjective) }\end{array}$} & None & 0 \\
\hline & Mild/non purulent & 1 \\
\hline & Purulent & 2 \\
\hline \multirow{3}{*}{$\begin{array}{l}\text { Radiographic } \\
\text { findings on chest } \\
\text { X-ray }\end{array}$} & No infiltrates & 0 \\
\hline & Diffuse/patchy infiltrates & 1 \\
\hline & Localized infiltrate & 2 \\
\hline \multirow{3}{*}{$\begin{array}{l}\text { Culture result } \\
\text { (respiratory } \\
\text { sampling) }\end{array}$} & No/mild growth & 0 \\
\hline & Moderate/florid growth & 1 \\
\hline & $\begin{array}{l}\text { Moderate/florid growth } \\
\text { and pathogen consistent } \\
\text { with Gram stain }\end{array}$ & 2 \\
\hline \multirow{2}{*}{$\begin{array}{l}\text { Oxygenation } \\
\text { status }\left(\mathrm{PaO}_{2} / \mathrm{FiO}_{2}\right. \\
\text { ratio) }\end{array}$} & $>240$ or ARDS & 0 \\
\hline & $\begin{array}{l}\leq 240 \text { and absence of } \\
\text { ARDS }\end{array}$ & 2 \\
\hline
\end{tabular}


was $>$ ODc and $\leq 2 \mathrm{x}$ ODc, and negative biofilm if bacterial OD was $<_{-}$ODc value.

VAP was defined as CPIS of $\geq 6$ at 48 th h postmechanical ventilation. The data recorded for CPIS were; body temperature, leukocyte count, tracheal secretion characteristic, oxygenation, culture of tracheal aspirate specimen, and chest $\mathrm{X}$-ray (Table 1).

Statistical Analysis: We used Spearman's rank correlation coefficient to determine the correlation between biofilm and VAP diagnosis. Subsequently, we used Kendall's tau-b correlation to find the direction of the correlation between increasing biofilm production and VAP diagnosis. We used IBM Statistical Product and Service Solutions (SPSS) version 25 to analyze the data.

\section{Results}

During the 6-month study period, 49 mechanically ventilated patients met our inclusion criteria. Of these, 12 subjects were dropped out due to being extubated and death before the 48th hour of ventilation. Most of our study subjects were patients undergoing intensive care after elective or emergency operative procedures. Our study subjects were predominantly males, e.g., $56.75 \%$ vs. $43.25 \%$ being the females. Most of study subjects were between 19 and $60 \mathrm{y}$ old (81.08\%) (Table 2).

Of the 37 samples we obtained negative biofilm in 23 samples and positive biofilm in 14 samples comprising 10 with weak biofilm concentration and 4 with moderate biofilm concentration (Figure 1). Of these positive biofilms, 9 samples were identified as to be with VAP, as they had CPIS of $\geq 6$ (Figure 2).

We found that only $14.8 \%$ (23/27) of the biofilmnegative group had CPIS of 6 or higher, which raises the possibility of VAP. In the weak biofilm-producing group, 30\% (3/10) had CPIS of 6 or higher. We found that $50 \%(2 / 4)$ of the moderate biofilm-producing group had high CPIS indicating VAP.

We obtained 48 specimens and found that Gramnegative bacteria were more common cause of VAP than Gram-positive bacteria ( $81 \%$ vs $17 \%)$. There was one unidentified microorganism (2\%).

We used Spearman's rank correlation to find a correlation between biofilm
Table 2: Demographic characteristics of the subjects

\begin{tabular}{|c|c|c|}
\hline Parameter & n & Percentage \\
\hline \multicolumn{3}{|l|}{ Sex } \\
\hline Male & 21 & $56.75 \%$ \\
\hline Female & 16 & $43.25 \%$ \\
\hline \multicolumn{3}{|l|}{ Age (y) } \\
\hline $19-60$ & 30 & $81.08 \%$ \\
\hline 260 & 7 & $18.92 \%$ \\
\hline \multicolumn{3}{|c|}{ Reason for ventilation } \\
\hline Elective Surgery & 4 & $13.51 \%$ \\
\hline Emergency Surgery & 19 & $51.35 \%$ \\
\hline Medical & 13 & $35.14 \%$ \\
\hline \multicolumn{3}{|l|}{ Temperature $\left({ }^{\circ} \mathrm{C}\right)$} \\
\hline$<38$ & 41 & $91.11 \%$ \\
\hline$\geq 38$ & 4 & $8.89 \%$ \\
\hline \multicolumn{3}{|c|}{ Blood glucose level (mg/100 ml) } \\
\hline$<200$ & 37 & $82.22 \%$ \\
\hline 2200 & 8 & $17.78 \%$ \\
\hline \multicolumn{3}{|l|}{ CPIS } \\
\hline$<6$ & 28 & $75,68 \%$ \\
\hline$\geq 6$ & 9 & $24,32 \%$ \\
\hline \multicolumn{3}{|l|}{ Biofilm } \\
\hline Negative & 23 & $62,16 \%$ \\
\hline Weak & 10 & $27,03 \%$ \\
\hline Moderate & 4 & $10,81 \%$ \\
\hline
\end{tabular}

production and VAP diagnosis through CPIS. Spearman's correlation test revealed adequate significant correlation between biofilm and CPIS $\geq 6$ $(\rho=0.341, p=0.039)$. To see the direction between these two variables, we used Kendall's tau-b test. Kendall's tau-b test showed that biofilm production had adequate significantly correlated with the increase in CPIS ( $\tau \mathrm{b}=0.341, \mathrm{p}=0.041)$ (Table 3$)$.
Table 3: Correlation between Biofilm Production and VAP

\begin{tabular}{l|l|l|l}
\hline Statistical test & $\mathbf{n}$ & Correlation coefficient & $\mathbf{p}$ \\
\hline Spearman's rank correlation & 37 & $0.341^{*}$ & 0.039 \\
\hline Kendall tau-b & 37 & $0.341^{\star *}$ & 0.041 \\
\hline * defined as rho $(\rho)$, ** defined as tau-b (זb) & &
\end{tabular}




\section{Discussion}

Antibiotics play an important role in VAP therapy. ${ }^{12}$ Inappropriate antibiotics increase the risk of microbial antibiotic resistance. We provide an alternative method of identification of the etiological bacteria of VAP by using a quantitative biofilm method based on culture of bacteria. The most common method to achieve this is through biofilm quantitative assay using microtiter plate. ${ }^{11}$ Thus, appropriate antibiotic for responsible pathogen bacteria can be administered to reduce the incidence of multidrug resistance. ${ }^{13,14}$

Previous studies by Danin in 2015 found that biofilm was present in subjects with ETT regardless of the duration of being on mechanical ventilation. ${ }^{7}$ This is not in line with our findings in which only 14 samples out of 37 samples had biofilm. This discrepancy may be due to the different method in examining biofilm. In this study, we examined the quantitative biofilm using sputum from ETT analyzed using a microtiter plate method while Danin et al. used samples from ETT lumen analyzed using electron microscopy for the quantitative assay.

This study used endotracheal aspirates (ETA) as the sputum sample. Based on the guidelines, ETA is a noninvasive sputum extraction method. ${ }^{15,16,17}$ This study also points out that adequate sputum samples are important for analysis. ${ }^{18,19}$ Based on the study by Perotin et al., in 2012, biofilm is supposed to be identified if the sample collection is not from sputum but directly from the tube lumen. This study also revealed that Gram-negative bacteria were the primary cause of $\mathrm{VAP},{ }^{4}$ a similar finding to that of our study.

We used CPIS because it has been widely used as a reliable diagnostic tool for diagnosing AP. The sensitivity of CPIS system is higher than relying on clinical criteria alone, the current gold standard for diagnosing VAP. ${ }^{20-22}$ CPIS analysis has $89 \%$ sensitivity and $47 \%$ specificity for diagnosing VAP. ${ }^{23}$ Our study revealed that after being mechanical ventilation for $48 \mathrm{~h}, 9$ patients had CPIS $\geq 6$ and were

\section{CPIS Results}

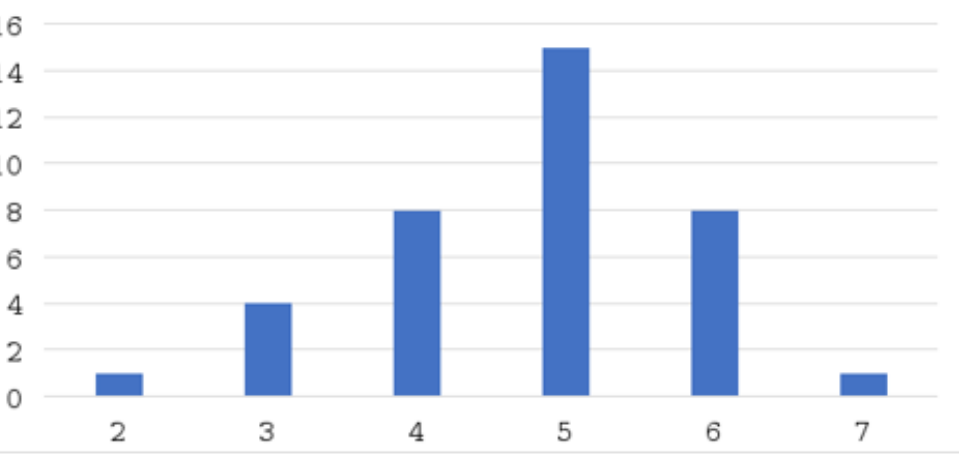

Figure 1: CPIS Results

\section{Biofilm Production Based on VAP Diagnosis}

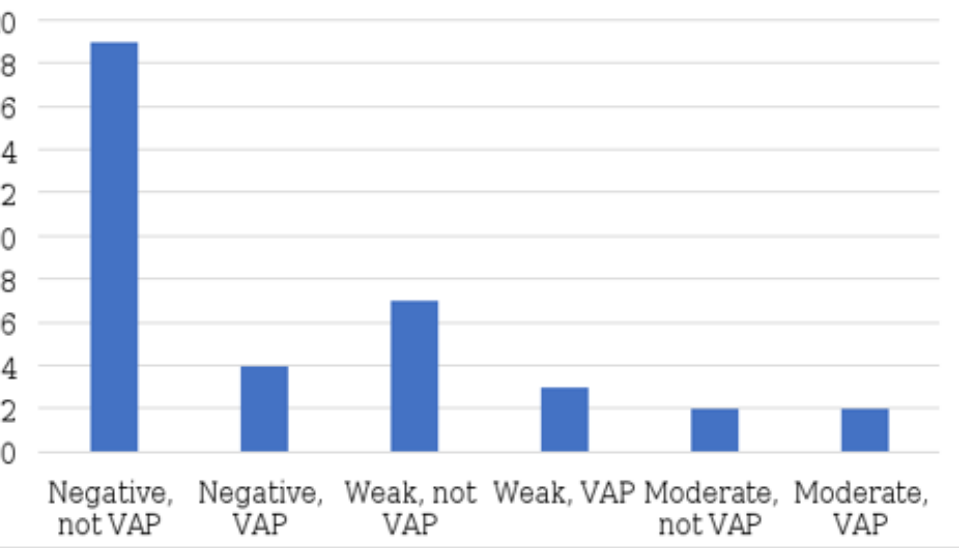

Negative, Negative, Weak, not Weak, VAP Moderate, Moderate,

2: Biofilm production based on VAP diagnosis

diagnosed with VAP. A study by Azmy M stated that the duration of being on ETT influenced the diagnosis of VAP. The incidence of VAP increased significantly in patients with ETT for more than 5 days. ${ }^{24}$

Antibiotic resistance has become a major concern today. Therefore, using a faster and more precise diagnosis can support more appropriate therapy and reduce multidrug resistance related to VAP. Based on our results it is suggested that biofilm quantitative with microtiter plate method should be routinely conducted on patients who are mechanically ventilated.

\section{Limitations}

Our study is limited by several factors. First of all, the sputum samples were obtained from ETA. This method is unknown as the best method for sputum extraction. However, this procedure is also used in other studies because it is noninvasive and the result is similar to that of invasive sputum extraction. This sputum extraction method does not require special 
tools and skills in the process. Secondly, we only used adequate sputum samples. Lastly, we diagnosed VAP only at 48th hours after the patient was mechanically ventilated. Although this is a gold standard, several studies do find that longer duration of ET correlates with VAP.

\section{Conclusion}

Quantitative biofilm measurement can be an alternative diagnostic tool for diagnosing VAP to give appropriate therapy.

\section{Conflict of interest}

No conflicts of interest/competing interest was declared by the authors.

\section{Authors' contribution}

Suradi and Bambang Purwanto: Supervised the research and assessment of research report process

Brian Wasita: Conceived and designed the analysis

Fitri Hapsari Dewi: Literature search, collected and analyzed data, and wrote the manuscript.

\section{References}

1. Diaconu O, Siriopol I, Poloșanu LI, Grigoraș I. Endotracheal tube biofilm and its impact on the pathogenesis of ventilator-associated pneumonia. J Crit Care Med. 2018;4(2):50-5. [PubMed] DOI: 10.2478/jccm-2018-0011

2. Timsit JF, Esaied W, Neuville M, Bouadma L, Mourvllier B. Update on ventilator-associated pneumonia. F1000Res. 2017;6(0):1-13. [PubMed] DOI: 10.12688/f1000research.12222.1

3. Kalil AC, Metersky ML, Klompas M, Muscedere J, Sweeney DA, Palmer LB, et al. Management of Adults With Hospital-acquired and Ventilator-associated Pneumonia: 2016 Clinical Practice Guidelines by the Infectious Diseases Society of America and the American Thoracic Society. Clin Infect Dis. 2016;63(5):e61-111. [PubMed] DOI: 10.1093/cid/ciw353

4. Gil-Perotin S, Ramirez P, Marti V, Sahuquillo JM, Gonzalez E, Calleja I, et al. Implications of endotracheal tube biofilm in ventilator-associated pneumonia response: A state of concept. Crit Care. 2012;16(3):R93. [PubMed] DOI: $10.1186 /$ cc11357

5. Vestby LK, Grønseth T, Simm R, Nesse LL. Bacterial biofilm and its role in the pathogenesis of disease. Antibiotics. 2020;9(2). [PubMed] DOl: 10.3390/antibiotics9020059
6. Emonet S, Lazarevic V, Leemann Refondini C, Gaïa N, Leo $S$, Girard $M$, et al. Identification of respiratory microbiota markers in ventilator-associated pneumonia. Intensive Care Med. 2019;45(8):1082-92. [PubMed] DOI: $10.1007 / \mathrm{s} 00134-019-05660-8$

7. Danin PE, Girou E, Legrand P, Louis B, Fodil R, Christov $C$, et al. Description and microbiology of endotracheal tube biofilm in mechanically ventilated subjects. Respir Care. 2015;60(1):21-9. [PubMed] DOI: 10.4187/respcare.02722

8. Schooneveld T Van. Antibiotic protocol for empiric therapy of nosocomial pneumonia: Health-Care Associated Pneumonia (HCAP), Hospital-Acquired Pneumonia (HAP); 2015. Available from: https://www.unmc.edu/intmed/divisions/id/asp/clinicalpathways/docs/hcap-hap-vap-guidance-2015revision.pdf

9. Kırmusaoğlu S. The Methods for detection of biofilm and screening antibiofilm activity of agents. Antimicrobials, Antibiotic Resistance, Antibiofilm Strategies and Activity Methods. 2019;1-17. DOI: 10.5772/intechopen.84411

10. Wilson C, Lukowicz R, Merchant S, Valquier-Flynn H, Caballero J, Sandoval J, et al. Quantitative and qualitative assessment methods for biofilm growth: a mini-review. Res Rev J Eng Technol. 2017;6(4). [PubMed]

11. O'Toole GA. Microtiter dish Biofilm formation assay. J Vis Exp. 2010;(47):3-5. [PubMed] DOI: 10.3791/2437

12. Roquilly A, Feuillet $F$, Seguin $P$, Lasocki S, Cinotti R, Launey $Y$, et al. Empiric antimicrobial therapy for ventilator-associated pneumonia after brain injury. Eur Respir J. 2016;47(4):1219-28. [PubMed] DOI: 10.1183/13993003.01314-2015

13. Arthur LE, Kizor RS, Selim AG, van Driel ML SL. Antibiotics for ventilator-associated pneumonia Cochrane Database Syst Rev. 2016;(10). [PubMed] DOI: $\underline{10.1002 / 14651858 . C D 004267 . p u b 4}$

14. Xie X, Lyu J, Hussain T, Li M. Drug prevention and control of ventilator-associated pneumonia. Front Pharmacol. 2019 Mar 28;10:298. [PubMed] DOI: 10.3389/fphar.2019.00298

15. Torres A, Niederman MS, Chastre J, Ewig S, Fernandez-Vandellos $P$, Hanberger $H$, et al. International ERS/ESICM/ESCMID/ALAT guidelines for the management of hospital-acquired pneumonia and ventilator-associated pneumonia. Eur Respir J. 2017 $\begin{array}{lll}\text { Sep 10;50(3):1700582. [PubMed] DOI: } & \end{array}$ $\underline{10.1183 / 13993003.00582-2017}$

16. imsit JF, Esaied W, Neuville M, Bouadma L, Mourvllier B. Update on ventilator-associated pneumonia. F1000Res. 2017 Nov 29;6:2061. [PubMed] DOI: 10.12688/f1000research.12222.1

17. Miller F. Intensive tutorial 382 ventilator associated pneumonia. WFSA. 2018;June:1-6. Available from: https://www.wfsahq.org/components/com_virtual_librar $\mathrm{y} / \mathrm{media} / 5 \mathrm{e} 63 \mathrm{c} 8 \mathrm{f} 14 \mathrm{e} 8 \mathrm{a} 46 \mathrm{c} 186 \mathrm{bb} 0 \mathrm{f} 73$ eafa2950-atow382-00-01.pdf

18. Del Rio-Pertuz G, Gutiérrez JF, Triana AJ, Molinares JL, 
Dewi FH, et al.

Robledo-Solano AB, Meza JL, et al. Usefulness of sputum gram stain for etiologic diagnosis in communityacquired pneumonia: A systematic review and metaanalysis. BMC Infect Dis. 2019;19(1):403. [PubMed] DOI: $\underline{10.1186 / s 12879-019-4048-6}$

19. Vernikos $\mathrm{P}$, Kampolis CF, Konstantopoulos K, Armaganidis A, Karakitsos $P$. The role of bronchoscopic findings and bronchoalveolar lavage fluid cytology in early diagnosis of ventilator-associated pneumonia. Respir Care. 2016;61(5):658-67. [PubMed] DOI: 10.4187/respcare.04265

20. Torres A, Niederman MS, Chastre J, Ewig S, Fernandez-Vandellos $\mathrm{P}$, Hanberger $\mathrm{H}$, et al. International ERS/ESICM/ESCMID/ALAT guidelines for the management of hospital-acquired pneumonia and ventilator-associated pneumonia. Eur Respir J. 2017;50(3). [PubMed] DOI: 10.1183/13993003.00582$\underline{2017}$

21. Zilberberg MD, Shorr AF. Ventilator-associated
Quantitative biofilm for bacterial pathogens

pneumonia: the clinical pulmonary infection score as a surrogate for diagnostics and outcome. Clin Infect Dis. 2010 Aug 1;51 Suppl 1:S131-5 [PubMed] DOI: 10.1086/653062

22. CDC M. Pneumonia (Ventilator-associated [VAP] and non-ventilator-associated Pneumonia [PNEU]) Event. CDC. 2018. Available from: https://www.cdc.gov/nhsn/pdfs/pscmanual/6pscvapcurr ent.pdf

23. Başyiğit S. Clinical pulmonary infection score (CPIS) as a screening tool in ventilatory associated pneumonia (VAP). SiSli Etfal Hastan Tip Bul / Med Bull Sisli Hosp. 2017;(2):133-41. 10.5350/SEMB.20170208030528

24. Azmy M, Ghanem L, Zahraa F El, Gamal D, Abdelkhalek A, El-Kholy $E$, et al. Biofilm on endotracheal tubes. 2012;274. Available from: https://www.escmid.org/guidelines_publications/escmid elibrary/material/?mid=50289 